\title{
Contributions of Leaf Rust Resistance and Awns to Agronomic and Grain Quality Performance in Winter Wheat
}

\author{
J. N. Martin, B. F. Carver,* R. M. Hunger, and T. S. Cox
}

\begin{abstract}
Wheat (Triticum aestivum L.) cultivars grown in the Great Plains usually bear awned spikes for their putative value to grain yield and quality. Awnletted cultivars are generally limited to forage-only systems. We hypothesized that an awnletted type would be more acceptable to grain producers if flag leaf senescence is delayed by protection against leaf rust (caused by Puccinia triticina Erikss.), the principal foliar disease affecting wheat production in the southern Great Plains. In field experiments under moderate levels of leaf rust infection, our objective was to estimate the effects of awns and leaf rust resistance according to the action and interaction of genes controlling these traits. Our analysis focused on agronomic and quality attributes previously shown to be influenced by these genes. Experimental lines were developed from crosses between leaf rust-susceptible (awnletted or awned) near-isolines of 'Century' and two leaf rust-resistant, awned backcrossed-derived lines with $\mathbf{L r} 41$ or $\mathbf{L r} 42$ from Triticum tauschii (Coss.) Schmal. For most attributes, genes controlling awns and rust resistance acted additively but with unequal effects. For the average effects of $L r 41$ and $L r 42$, grain yield increased by 63 and $26 \%$, test weight increased by 5 and $3 \%$, and kernel weight increased by 14 and $9 \%$. Averaged across resistant and susceptible types for each gene, awns increased yield by 6.2 and $0 \%$, increased test weight by $1.7 \%$ (either $\mathrm{Lr}$ gene source), and increased kernel weight by 6 and $4 \%$. Rust resistance was more effective in compensating for the absence of awns than awns were in compensating for the lack of rust resistance. Leaf rust resistance improved milling quality by increasing flour yield and kernel diameter, independent of the presence or absence of awns. The development of awnletted cultivars with acceptable grain yield potential and quality appears achievable, but their utility in a grainonly production system will be limited without leaf rust resistance.
\end{abstract}

\begin{abstract}
$A^{\mathrm{w}}$ WNLETTED CULTIVARS still remain a novelty in hard red winter (HRW) wheat production in the U.S. Great Plains. Their obscurity in this region relates to the traditional emphasis by breeders on the awned genotype and to a perception by producers that awnletted cultivars lack the grain yield performance of awned cultivars. Awnletted cultivars that have experienced some popularity, e.g., 'Longhorn' and 'Lockett', gained their reputation primarily on forage production in graze-out or forage-only management systems, where they pose less mouth and eye irritation to livestock. These cultivars have seen limited use in grain production, whether or not preceded by forage removal, where their demand for cultivation would be much greater. Awnletted cultivars

J.N. Martin and B.F. Carver, Dep. of Plant and Soil Sciences; R.M. Hunger, Dep. of Entomology and Plant Pathology, Oklahoma State Univ., Stillwater, OK 74078; T.S. Cox, The Land Institute, 2440 E. Water Well Rd., Salina, KS 67401. Part of a dissertation submitted by J.N. Martin in partial fulfillment of the M.S. degree requirements at Oklahoma State Univ. Received 27 July 2002. *Corresponding author(bfc@okstate.edu).
\end{abstract}

Published in Crop Sci. 43:1712-1717 (2003).

(c) Crop Science Society of America

677 S. Segoe Rd., Madison, WI 53711 USA that possess grain yield and end-use quality equivalent to contemporary awned cultivars would find acceptance in the southern Great Plains, because they give producers the added flexibility to defer their decision to use a standing crop either for grain production or for hay or late-season grazing.

Because the awns in wheat are photosynthetically active and have direct vascular linkage with the developing spike, their suppression potentially reduces the total photosynthetic contribution to developing kernels (Weyhrich et al., 1995). Reduced photosynthate supply could translate into lower kernel weight and test weight (Olugbemi et al., 1976) and possibly reduced grain yield (McKenzie, 1972). More recent evidence from the southern Great Plains was furnished by a comprehensive analysis of the contribution of awns in three genetic backgrounds and 78 sister-line pairs of HRW wheat (Weyhrich et al., 1994). For the majority of sister-line comparisons, awn suppression had no significant effect on grain yield, but it did reduce test weight (mean difference of $31 \mathrm{~kg} \mathrm{~m}^{-3}$ ) and kernel weight (mean difference of $2.2 \mathrm{~g}$ per 1000 kernels). Wheat protein and hardness measurements were not consistently influenced by awn suppression in the parent bulk populations of those sister-line pairs.

We would expect foliar disease pressure to influence comparisons of awned and awnletted genotypes for grain yield and kernel weight. Grain yield and kernel weight may decline with disease development on the flag leaf in amounts proportional to the decline in green leaf area duration (Gooding et al., 2000). Leaf rust remains a significant foliar disease of winter wheat in the southern and central Great Plains. From 1976 to 2000, the estimated average grain yield loss caused by leaf rust was $3.5 \%$, exceeding other diseases by more than two-fold (Bockus et al., 2001). The benefit of leaf rust resistance to grain production and quality can be substantial, even among a wide array of conditions, which benefits are measured (Drijepondt et al., 1990; Cox et al., 1997; Singh and Huerta-Espino, 1997). We hypothesized that the presence of effective leaf rust resistance genes might extend flag leaf area duration and thereby compensate for the absence of awns in awnletted genotypes. Conversely, awns could provide some photosynthetic compensation in the event of premature flag leaf senescence under rust development.

Field experiments were designed, featuring natural infection by Puccinia triticina, to more precisely estimate the single and joint effects of awns and leaf rust resistance. We chose to investigate two independent leaf rust resistance genes, $L r 41$ and $L r 42$, given their current role in providing effective resistance in the southern Great Plains. Our analysis focused on agronomic properties previously shown to be influenced by these genes, 
as well as several quality characteristics under continual selection pressure in hard wheat breeding programs. A secondary objective was to assess the relative merits of Lr41and $L r 42$ for trait improvement.

\section{MATERIALS AND METHODS}

Two series of near-isogenic lines (NILs) were developed with the intent to restrict genotypic variation except for genes segregating for leaf rust resistance and awn formation. Each series featured a unique leaf rust resistance gene from two backcross-derived lines of the HRW cultivar, Century. The first line, designated KS93U62, had the pedigree Century*3/ TA2460, in which TA2460 was an accession of Triticum tauschii containing Lr41 (Cox et al., 1994). The second line, designated KS93U50, was a selection from KS91WGRC11 (PI 56668 ) with the pedigree Century*3/TA2450, in which TA2450 was a $T$. tauschii accession containing $L r 42$.

KS93U62 and KS93U50 were crossed with OK92G205 (PI 561731 ), an awnletted NIL of Century with the pedigree Century*5/'McNair 1003' (Carver et al., 1993). The soft red winter wheat, McNair 1003, provided the awnletted character. Each cross produced a $\mathrm{F}_{2}$ population cosegregating at one of the leaf rust resistance loci ( $L r 41$ and $L r 42$, respectively) and a locus controlling awn formation. Phenotypes were scored among $>200 \mathrm{~F}_{2}$ plants per cross grown in the greenhouse at Manhattan, KS, with artificial inoculation of seedlings with $P$. triticina. Four genotypic classes were identified: resistant, homozygous awned; susceptible, homozygous awned; resistant, homozygous awnletted; and susceptible, homozygous awnletted. Detection of homozygosity at the awn locus was aided by intermediate expression of awn formation by heterozygotes. The homozygous condition for leaf rust reaction was confirmed in the following generation at Stillwater, OK (May, 1997). We identified nonsegregating $F_{2: 3}$ families on the basis of adult-plant responses in the field under moderately heavy, natural development of leaf rust. Random families representing the four genotypic classes were grouped according to their original cross, and these were identified as series $41 \mathrm{~A}$ (KS93U62/OK92G205 progenies) and series 42A (KS93U50/ OK92G205 progenies) (Table 1).
A third series was developed from crosses of KS93U62 and KS93U50 with OK92G206 (PI 561733), an awned NIL of OK92G205 (Carver et al., 1993). We used these progenies to compare the two sources of leaf rust resistance directly, independent of segregation for awn formation. Resistant and susceptible awned genotypes were combined from both crosses and identified as series 41/42 (Table 1). Phenotypic classification was as described above, producing four classes of genotypes: leaf rust resistant and susceptible lines derived from KS93U62 ( Lr41) and from KS93U50 ( $L r 42)$.

Experiments were conducted at Stillwater, OK, in 1998 and at Stillwater and Lahoma, OK, in 1999. Each of the three series was arranged independently in the field in a randomized complete block design with four replicates. The four parents, KS93U62, KS93U50, OK92G205, and OK92G206, were included as checks depending on the parental origin of each series. The same cultural practices were applied to each series, including fertilizer applications (according to soil-test recommendations for a $2600 \mathrm{~kg} \mathrm{ha}^{-1}$ yield goal), planting date (early to mid-October), planting rate (approx. $60 \mathrm{~kg} \mathrm{ha}^{-1}$ ), and plot size (either $1.83 \mathrm{~m}^{2}$ in 1998 or $3.45 \mathrm{~m}^{2}$ in 1999).

Development of leaf rust depended entirely on natural infection. Approximately 2 wk after heading, leaf rust reactions were recorded at Stillwater on 13 May 1998 according to the modified Cobb scale (Peterson et al., 1948) and on 19 May 1998 and 12 May 1999 according to a stay-green scale of 1 to 9. For the latter, increasing values represented increasing levels of susceptibility, in which 1 (not applicable in this study), 2 , and $3=4,3$, and 2 leaves, respectively, below the flag leaf mostly green; 4 = penultimate and flag leaf mostly green; $5=$ flag leaf mostly green; $6=$ flag leaf partially chlorotic; $7=$ flag leaf mostly chlorotic; $8=$ flag leaf severely chlorotic; and 9 = flag leaf necrotic.

As a supplement to these adult-plant field reactions, seedling reactions were determined in the greenhouse according to Browder (1971). A mixture of $P$. triticina urediniospores was collected in May 1999 from 10 HRW cultivars growing at three central Oklahoma locations. The avirulence-virulence formula of this mixture on a single-gene differential series ('Thatcher' background) plus 'Siouxland' $(L r 24+L r 26)$ and Century (Lr24) was 9171926 SXL/1 2a 2c 3 3ka 11162430

Table 1. Classification and phenotypic description for three series of near-isogenic experimental lines of 'Century' hard red winter wheat.

\begin{tabular}{|c|c|c|c|c|c|c|c|c|}
\hline \multirow[b]{2}{*}{ Series or parent } & \multirow[b]{2}{*}{ Pedigree } & \multicolumn{4}{|c|}{ Genotype class description } & \multicolumn{3}{|c|}{ Leaf rust reaction } \\
\hline & & $\begin{array}{c}\text { Rust } \\
\text { gene source }\end{array}$ & $\begin{array}{l}\text { Leaf rust } \\
\text { reaction } \dagger\end{array}$ & Awn type & $\begin{array}{l}\text { Number of } \\
\text { genotypes }\end{array}$ & $\begin{array}{c}\text { Stay-green } \\
\text { flag leaf } \\
\text { rating } \neq\end{array}$ & Adult-field § & $\begin{array}{c}\text { Seedling- } \\
\text { greenhousefI }\end{array}$ \\
\hline Series & & & & & & 1-9 & & \\
\hline \multirow[t]{4}{*}{$41 \mathrm{~A}$} & KS93U62/OK92G205 & $L r 41$ & $\mathbf{R}$ & Awned & 6 & 5.0 & $\mathbf{O R}$ & ; \\
\hline & & & & Awnletted & 10 & 4.9 & OR & ; \\
\hline & & & $\mathbf{S}$ & Awned & 10 & 8.7 & $90 \mathrm{~S}$ & $3+$ \\
\hline & & & & Awnletted & 6 & 8.7 & 90S & X3cn; \\
\hline \multirow{4}{*}{$42 \mathrm{~A}$} & KS93U50/OK92G205 & $L r 42$ & $\mathbf{R}$ & Awned & 11 & 5.3 & $0-1 R$ & X3-cn; \\
\hline & & & & Awnletted & 8 & 5.1 & $0-1 R$ & $3 \mathrm{cn}$ \\
\hline & & & $\mathbf{S}$ & Awned & 7 & 7.5 & $65-90 \mathrm{~S}$ & X3-cn; \\
\hline & & & & Awnletted & 6 & 7.6 & $65-90 S$ & $3 \mathrm{cn}$ \\
\hline \multirow[t]{4}{*}{$41 / 42$} & KS93U62/OK92G206 & Lr41 & $\mathbf{R}$ & Awned & 11 & 5.0 & $\mathbf{O R}$ & \\
\hline & & & $\mathbf{S}$ & & 8 & 8.8 & $80-90 S$ & X3cn; \\
\hline & KS93U50/OK92G206 & $L r 42$ & $\mathbf{R}$ & & 6 & 5.9 & $\mathbf{O R}$ & X3-cn; \\
\hline & & & $\mathbf{S}$ & & 7 & 8.5 & $40-65 S$ & $3 \mathrm{cn}$ \\
\hline \multicolumn{9}{|l|}{ Parent } \\
\hline OK92G205 & Century*5/McNair 1003 & & $\mathbf{S}$ & Awnletted & - & 8.9 & $90 \mathrm{~S}$ & $3 \mathrm{cn}$ \\
\hline OK92G206 & Century*5/McNair 1003 & & $\mathbf{S}$ & Awned & - & 8.8 & $90 \mathrm{~S}$ & $\mathbf{X 3 c n}$ \\
\hline KS93U62 & Century*3/TA2460 & Lr41 & $\mathbf{R}$ & Awned & - & 4.8 & $\mathbf{O R}$ & \\
\hline KS93U50 & Century*3/TA2450 & Lr42 & $\mathbf{R}$ & Awned & - & 5.4 & $0-1 R$ & X3-cn; \\
\hline
\end{tabular}

$\dagger \boldsymbol{R}=$ resistant, $\mathrm{S}=$ susceptible to leaf rust based on adult plant field reactions.

\$ Taken approximately 2 wk after heading at Stillwater, OK, during May 1998 and 1999, where $5=$ flag leaf mostly green and $9=$ flag leaf necrotic; compute LSD (0.05) as $t(\mathrm{SD})\left(\left[n_{1}+n_{2}\right] / n_{1} n_{2}\right)^{1 / 2}$, where $n_{1}$ and $n_{2}$ are the number of observations (no. of genotypes per class $\times 4$ replicates $\times 2$ environments) used to compute each mean, and $t(\mathrm{SD})=1.3$ for $41 \mathrm{~A}, 2.4$ for $42 \mathrm{~A}$, and 1.5 for $41 / 42$ means comparisons.

$\S$ Modified Cobb scale, recorded 13 May 1998 at Stillwater on adult plants.

II Results of single-gene differential series (Thatcher background) determined on the basis of a mixture of urediospores collected in Oklahoma in May 1999; rating system according to Stakman et al. (1962). 
CTY. We inoculated first leaves of 10 to 15 seedlings of each NIL and parent by brushing them with 'Danne' seedlings on which $P$. triticina was profusely sporulating. After inoculation, seedlings were kept in a mist chamber at 20 to $22^{\circ} \mathrm{C}$ for $16 \mathrm{~h}$ and then moved to greenhouse benches. Leaf rust reaction was rated 10 to $12 \mathrm{~d}$ later according to Stakman et al. (1962).

Agronomic attributes were measured on all plots, totaling four replicates in each of three environments. Grain yield was determined as the weight of threshed, cleaned grain. Test weight was measured according to standard procedures with a 0.95 -L container. Kernel weight per 1000 kernels was calculated from the weight of a 200-kernel sample per plot.

All quality attributes were determined at the Oklahoma State University Wheat Quality Laboratory. Kernel hardness and kernel diameter were determined with the Perten Single Kernel Characterization System (SKCS, Perten Instruments, Reno, NV) from a sample of 300 sounds kernels per plot. We measured grain protein content by near-infrared reflectance (NIR) spectroscopy of a 9-g ground-wheat sample (method 39-70, AACC, 1995) and reported it on a $140 \mathrm{~g} \mathrm{~kg}^{-1}$ basis. Three replicates from each environment were sampled for kernel hardness, kernel diameter, and wheat protein.

After cleaning and tempering 125-g grain samples to $155 \mathrm{~g}$ $\mathrm{kg}^{-1}$ moisture, they were milled on a Brabender Quadrumat senior mill (C.W. Brabender instruments, South Hackensack, NJ) to estimate flour yield by AACC method 12-10A (AACC, 1995). Flour yield was reported on a $140 \mathrm{~g} \mathrm{~kg}^{-1}$ basis. Mixing characteristics of the milled flour were evaluated with a computer-assisted mixograph and 10-g bowl (National Manufacturing Co., Lincoln, NE) according to method 54-40 (AACC, 1995). Mixing time was the number of minutes needed for optimal dough development and was adjusted for flour samples with $<120 \mathrm{~g} \mathrm{~kg}^{-1}$ protein on the basis of NIR spectroscopy. Mixing tolerance was determined in two ways: (i) by a subjective scale of 1 to 10 based on visual comparison of the mixogram to 10 standard tracings with comparable flour protein content and (ii) by the actual width of the mixogram curve at 2 min past peak development. Scores from the subjective scale were interpreted as 1 to 2, poor mixing tolerance; 3 to 6 , moderate tolerance; and 7 to 10 , strong tolerance. We determined SDS-sedimentation values after adjusting for flour protein content, according to the method described by Carver (1994). Flour yield, mixograph properties, and SDS-sedimentation were reported from two replicates in two environments (Stillwater, 1998 and 1999).

After confirming error homogeneity across environments, the data were combined across environments for partitioning of the genetic variance in each series. Genetic effects associated with awn type and leaf rust resistance class (series $41 \mathrm{~A}$ and $42 \mathrm{~A}$ ) or with resistance gene background (series 41/42) were considered fixed, while other effects were considered random. For series $41 \mathrm{~A}$ and $42 \mathrm{~A}$, the genetic variation among 32 NILs was partitioned into single-df contrasts of resistant versus susceptible classes, awned versus awnletted classes, and their interaction. For the series 41/42, variation among the 32 NILs was partitioned into single-df contrasts of resistant versus susceptible classes, $L r 41$ versus $L r 42$ backgrounds, and their interaction. The error term used in $F$-tests and in constructing LSD values was derived from pooling the sums of squares within classes.

\section{RESULTS AND DISCUSSION}

Development of leaf rust was more severe in both years of this study than what was summarized on a regional basis by Krenzer et al. $(1998,1999)$ as relatively low for the Great Plains. Severity levels were sufficient to discern genotypic differences 2 wk after heading, defined as $50 \%$ of the heads fully emerged from the boot. In 1998 at Stillwater, heading occurred generally from 28 April to 1 May, whereas in 1999, heading occurred from 26 to 28 April. A uniform infection of Soilborne wheat mosaic virus (SBWMV) at Stillwater in 1999 led to plant stunting and subsequent yield reduction from 1998. The NILs were not differentially affected as expected on the basis of Century's susceptibility to SBWMV (Smith et al., 1989). Stay-green readings in both years were indicative of the degree of chlorosis and necrosis caused by leaf rust (Table 1).

Mean stay-green values for the four genotypic classes indicated distinct differences between the resistant (flag leaves mostly green) and susceptible lines (flag leaves mostly chlorotic to necrotic). Visual differences between resistant and susceptible classes were more apparent among NILs segregating for $L r 41$ than those segregating for $L r 42$. This was reflected in higher severity levels among susceptible lines derived from KS93U62 ( $L r 41$ source) than susceptible lines from KS93U50 ( $\mathrm{r} 42$ source) (Table 1). We found no visible infection among resistant lines with $L r 41$ (0R rating), whereas the resistant lines with $L r 42$ showed minimal visible infection (0-1R ratings). Seedling tests confirmed the resistance of lines with Lr41, but Lr42 appeared to confer resistance only in adult plants. As expected, no visual differences were noted in leaf rust reaction between awned and awnletted NILs within the same leaf rust response class.

\section{Agronomic Attributes}

From the analysis of variance for grain yield, test weight, and kernel weight, the genetic variation among NILs from series $41 \mathrm{~A}$ and $42 \mathrm{~A}$ consistently traced to a significant main effect of leaf rust reaction type ( $R$ vs. $S$, Table 2). The main effect of awn type $\left(\mathrm{A}^{+}\right.$vs. $\left.\mathrm{A}^{-}\right)$, with one exception, was also significant for these attributes. Resistance to leaf rust and the presence of awns generally improved agronomic performance. The interaction of leaf rust reaction type $\times$ awn type was not significant in five of six tests. Hence, the effect of adding awns was independent of the genotype for leaf rust reaction, or for the corollary, the effect of adding resistance was indifferent to the presence or absence of awns. Grain yield of the NILs segregating for $\mathrm{Lr} 42$ did show a significant interaction, as yield increased with the addition of awns on susceptible lines but not on resistant lines.

In the presence of leaf rust, and considering the effect of one factor averaged across the other, resistance to leaf rust increased grain yield in series $41 \mathrm{~A}$ and $42 \mathrm{~A}$ by 63 and $26 \%$, increased test weight by 5 and $3 \%$, and increased kernel weight by 14 and $9 \%$ (Table 2). Awns increased yield by $6.2 \%$ in $41 \mathrm{~A}$ (with no significant increase in $42 \mathrm{~A}$ ), increased test weight by $1.7 \%$ in both series, and increased kernel weight by 6 (series 41A) and $4 \%$ (series $42 \mathrm{~A}$ ). These results are consistent with gene effects estimated individually in other genetic backgrounds for awns (Weyhrich et al., 1994) and Lr41 (Cox et al., 1997).

Examination of the leaf rust reaction type $\times$ awn type 
Table 2. Agronomic means for testing main effects and interactions of leaf rust reaction and awn type (series $41 \mathrm{~A}$, $42 \mathrm{~A})$ across three Oklahoma environments.

\begin{tabular}{|c|c|c|c|c|c|c|c|}
\hline \multicolumn{8}{|c|}{ Genotypic class description $\nmid$} \\
\hline \multirow[b]{2}{*}{ Leaf rust reaction } & \multirow[b]{2}{*}{ Awn type } & \multicolumn{2}{|c|}{ Grain yield } & \multicolumn{2}{|c|}{ Test weight } & \multicolumn{2}{|c|}{ 1000-kernel weight } \\
\hline & & $41 \mathrm{~A}$ & $42 A$ & $41 \mathrm{~A}$ & $42 \mathrm{~A}$ & $41 \mathrm{~A}$ & $42 \mathrm{~A}$ \\
\hline & & \multicolumn{2}{|c|}{$\mathrm{kg} \mathrm{ha}^{-1}$} & \multicolumn{2}{|c|}{$\mathrm{kg} \mathrm{m}^{-3}$} & . & 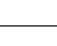 \\
\hline $\mathbf{R}$ & $\mathbf{A}^{+}+\mathbf{A}^{-}$ & 2880 & 2970 & 720 & 726 & 26.3 & 26.5 \\
\hline $\mathbf{S}$ & $\mathbf{A}^{+}+\mathbf{A}^{-}$ & 1770 & 2350 & 688 & 704 & 23.1 & 24.3 \\
\hline$F$-test for R vs. $\mathbf{S}$ & & $* *$ & $* *$ & $* *$ & $* *$ & $* *$ & $* *$ \\
\hline $\mathbf{R}+\mathbf{S}$ & $\mathbf{A}^{+}$ & 2400 & 2700 & 710 & 721 & 25.5 & 25.9 \\
\hline $\mathbf{R}+\mathbf{S}$ & $\mathbf{A}$ & 2260 & 2620 & 698 & 709 & 24.0 & 24.8 \\
\hline $\boldsymbol{F}$-test for $\mathbf{A}^{+}$vs. $\mathbf{A}^{-}$ & & $*$ & NS & $* *$ & ** & $* *$ & $* *$ \\
\hline \multirow[t]{2}{*}{ R } & $\mathbf{A}^{+}$ & 2930 & 2930 & 729 & 731 & 27.4 & 26.9 \\
\hline & $\mathbf{A}^{-}$ & 2840 & 3010 & 712 & 721 & 25.3 & 26.0 \\
\hline \multirow[t]{2}{*}{$\mathbf{S}$} & $\mathbf{A}^{+}$ & 1870 & 2460 & 692 & 711 & 23.6 & 24.9 \\
\hline & $\mathbf{A}^{-}$ & 1680 & 2230 & 684 & 697 & 22.7 & 23.6 \\
\hline$F$-test for interactions & & NS & $*$ & NS & NS & NS & NS \\
\hline$t(\mathrm{SD}) \div$ & & 1413 & 1356 & 63 & 59 & 8.7 & 6.1 \\
\hline
\end{tabular}

* Significant at $P=0.05$.

** Significant at $P=\mathbf{0 . 0 1}$.

$\dagger R=$ resistant, $S=$ susceptible to leaf rust; $A^{+}=$awned, $A^{-}=$awnletted; $41 \mathrm{~A}=$ lines cosegregating for $\operatorname{Lr} 41$ resistance and awns; $42 \mathrm{~A}=$ lines cosegregating for $\operatorname{Lr} 42$ resistance and awns.

$\$$ To compare rust reaction $\times$ awn type means, compute LSD $(0.05)$ as $t(\mathrm{SD})\left(\left[n_{1}+n_{2}\right] / n_{1} n_{2}\right)^{1 / 2}$, where $n_{1}$ and $n_{2}$ are the number of observations $($ no. of genotypes per class $\times 4$ replicates $\times 3$ environments) used to compute each mean.

means in Table 2 indicated that leaf rust resistance was more effective in compensating for the loss of awns (compare $\mathrm{RA}^{+}$vs. $\mathrm{RA}^{-}$classes) than awns were in compensating for the loss of leaf rust resistance (compare $\mathrm{RA}^{+}$vs. $\mathrm{SA}^{+}$means). Awned and awnletted classes had similar grain yields as long as they were resistant. In contrast, awned classes of resistant and susceptible genotypes differed substantially, with the susceptible lines having significantly lower yields. Making the same class comparisons for test weight and kernel weight, differences were always significant, but the patterns were similar to grain yield. Test weight and kernel weight were both reduced with the loss of awns, even with leaf rust resistance; the reduction was doubled when comparing resistant and susceptible NILs with awns.

We infer from the comparison of genotypic class means that awnletted and awned genotypes are indistinguishable for yield provided they are resistant to leaf rust, but the awnletted genotype may show some loss in test weight and kernel weight. Individual genotypes within classes did not show exception to those trends, though the within-class variation was significant $(P<$ $0.01)$ for all attributes in each series (not shown). Variation for grain yield was nonoverlapping between susceptible and resistant classes (awned or awnletted). The resistant, awned NILs produced the greatest kernel weights and test weights, whereas the susceptible, awnletted NILs produced the lowest. Differences between those classes amounted to about $40 \mathrm{~kg} \mathrm{~m}^{-3}(3.1 \mathrm{lb} / \mathrm{bu})$ in test weight and $4 \mathrm{~g}$ in 1000-kernel weight, constituting substantial losses in physical grain quality.

As noted above, the average effect of a resistance gene appeared to be larger for the $L r 41$ source of resistance than for the Lr42 source. Direct comparison of $L r 41$ and $L r 42$ was possible in series $41 / 42$ because NILs for the two genes were developed independently from those in $41 \mathrm{~A}$ and $42 \mathrm{~A}$ and tested concurrently. The interaction of gene source $\times$ leaf rust reaction was indeed significant for grain yield and for kernel weight (Table 3). This interaction reflected a larger difference

Table 3. Agronomic means for testing main effects and interactions of leaf rust resistance gene background and leaf rust reaction (series 41/42) across three Oklahoma environments.

\begin{tabular}{|c|c|c|c|c|}
\hline \multicolumn{5}{|c|}{ Genotypic class description } \\
\hline Resistance gene source & Leaf rust reaction $\dagger$ & Grain yield & Test weight & 1000-kernel weight \\
\hline & & $\mathbf{k g ~ h a}^{-1}$ & $\mathbf{k g ~ m}^{-3}$ & $\mathbf{g}$ \\
\hline Lr41 & $\mathbf{R}+\mathbf{S}$ & 2330 & 716 & 26.6 \\
\hline Lr42 & $\mathbf{R}+\mathbf{S}$ & 2430 & 725 & 26.2 \\
\hline$F$-test for $L r 41$ vs. $L r 42$ & & NS & $* *$ & NS \\
\hline$L r 41+L r 42$ & $\mathbf{R}$ & 2780 & 734 & 27.8 \\
\hline$L r 41+L r 42$ & S & 1980 & 707 & 25.0 \\
\hline$F$-test for R vs. $S$ & & $* *$ & $* *$ & $* *$ \\
\hline \multirow[t]{2}{*}{ Lr41 } & $\mathbf{R}$ & 2850 & 730 & 28.4 \\
\hline & $\mathbf{S}$ & 1820 & 703 & 24.8 \\
\hline \multirow[t]{2}{*}{$L r 42$} & $\mathbf{R}$ & 2700 & 737 & 27.3 \\
\hline & $\mathbf{S}$ & 2150 & 712 & 25.2 \\
\hline$F$-test for interactions & & $* *$ & NS & $* *$ \\
\hline$t(\mathrm{SD}) \div$ & & 1033 & 33 & 5 \\
\hline
\end{tabular}

* Significant at $\boldsymbol{P}=\mathbf{0 . 0 5}$.

** Significant at $P=0.01$.

$\dagger \boldsymbol{R}=$ resistant lines; $\mathbf{S}=$ susceptible to leaf rust.

$¥$ To compare source $\times$ rust reaction means, compute LSD $(0.05)$ as $t(\operatorname{SD})\left(\left[n_{1}+n_{2}\right] / n_{1} n_{2}\right)^{1 / 2}$, where $n_{1}$ and $n_{2}$ are the number of observations (no. of genotypes per class $\times 4$ replicates $\times 3$ environments) used to compute each mean. 
Table 4. Grain quality means for testing main effects and interactions of leaf rust reaction and awn type (series $41 \mathrm{~A}$, $42 \mathrm{~A})$ across two to three Oklahoma environments.

\begin{tabular}{|c|c|c|c|c|c|c|c|c|c|c|c|c|c|}
\hline \multirow{3}{*}{\multicolumn{2}{|c|}{ Genotypic class description $\dagger$}} & \multicolumn{4}{|c|}{ Single-kernel characterization system } & \multirow{3}{*}{\multicolumn{2}{|c|}{ Flour yield§ }} & \multirow{3}{*}{\multicolumn{2}{|c|}{ Wheat protein $\leftarrow$}} & \multirow{2}{*}{\multicolumn{4}{|c|}{ Mixograph§ }} \\
\hline & & \multirow{2}{*}{\multicolumn{2}{|c|}{$\begin{array}{c}\text { Kernel } \\
\text { diameter }\end{array}$}} & \multirow{2}{*}{\multicolumn{2}{|c|}{$\begin{array}{c}\text { Kernel } \\
\text { hardness }\end{array}$}} & & & & & & & & \\
\hline & & & & & & & & & & \multicolumn{2}{|c|}{ Rating } & \multicolumn{2}{|c|}{ Curve width } \\
\hline \multirow[t]{2}{*}{ Leaf rust reaction } & Awn type & $41 \mathrm{~A}$ & $42 A$ & $41 \mathrm{~A}$ & $42 \mathrm{~A}$ & $41 \mathrm{~A}$ & $42 A$ & $41 \mathrm{~A}$ & $42 \mathrm{~A}$ & $41 \mathrm{~A}$ & $42 \mathrm{~A}$ & $41 \mathrm{~A}$ & $42 \mathrm{~A}$ \\
\hline & & \multicolumn{2}{|c|}{$\mathbf{m m}$} & & & \multicolumn{4}{|c|}{$-\mathbf{g ~ k g}^{-1}$} & \multicolumn{2}{|c|}{$-1-10-$} & \multicolumn{2}{|c|}{$\mathbf{m m}$} \\
\hline $\mathbf{R}$ & $\mathbf{A}^{+}+\mathbf{A}^{-}$ & 2.1 & 2.0 & 77 & 75 & 682 & 651 & 124 & 123 & 4.6 & 4.1 & 11.4 & 9.5 \\
\hline $\mathbf{S}$ & $\mathbf{A}^{+}+\mathbf{A}^{-}$ & 1.9 & 1.9 & 76 & 77 & 662 & 637 & 123 & 122 & 4.9 & 4.3 & 12.5 & 11.2 \\
\hline$F$-test for R vs. $S$ & & $* *$ & $* *$ & $*$ & $* *$ & $*$ & $* *$ & NS & NS & NS & NS & $*$ & $* *$ \\
\hline $\mathbf{R}+\mathbf{S}$ & $\mathbf{A}^{+}$ & 2.0 & 2.0 & 75 & 75 & 679 & 647 & 124 & 122 & 4.7 & 4.2 & 11.8 & 10.6 \\
\hline $\mathbf{R}+\mathbf{S}$ & $\mathbf{A}^{-}$ & 1.9 & 1.9 & 78 & 77 & 666 & 641 & 124 & 122 & 4.8 & 4.2 & 12.2 & 10.1 \\
\hline $\boldsymbol{F}$-test for $\mathbf{A}^{+}$vs. $\mathbf{A}^{-}$ & & * & $* *$ & ** & ** & NS & NS & NS & NS & NS & NS & NS & NS \\
\hline \multirow[t]{2}{*}{$\mathbf{R}$} & $\mathbf{A}^{+}$ & 2.1 & 2.0 & 75 & 75 & 696 & 656 & 124 & 123 & 4.5 & 4.1 & 11.1 & 9.3 \\
\hline & $\mathbf{A}^{-}$ & 2.0 & 2.0 & 78 & 75 & 668 & 646 & 124 & 122 & 4.7 & 4.1 & 11.8 & 9.7 \\
\hline \multirow[t]{2}{*}{$\mathbf{S}$} & $\mathbf{A}^{+}$ & 1.9 & 1.9 & 76 & 76 & 661 & 638 & 123 & 122 & 4.8 & 4.4 & 12.5 & 11.9 \\
\hline & $\mathbf{A}^{-}$ & 1.8 & 1.8 & 77 & 78 & 663 & 636 & 124 & 122 & 5.0 & 4.3 & 12.5 & 10.6 \\
\hline$F$-test for interactions & & NS & NS & NS & $*$ & NS & NS & NS & NS & NS & NS & NS & \\
\hline$t(\mathrm{SD}) \mathrm{q}$ & & 0.5 & 0.2 & 7 & 7 & 84 & 57 & 8 & 10 & 1.7 & 3.4 & 4.4 & 5.9 \\
\hline
\end{tabular}

* Significant at $P=\mathbf{0 . 0 5}$.

** Significant at $\boldsymbol{P}=\mathbf{0 . 0 1}$.

$\dagger R=$ resistant, $S=$ susceptible to leaf rust; $A^{+}=$awned, $A^{-}=$awnletted; $41 A=$ lines co-segregating for $L r 41$ resistance and awns; $42 A=$ lines cosegregating for $\mathrm{Lr} 42$ resistance and awns.

$\$ 3$ replicates in each of 3 environments.

$\$ 2$ replicates in each of 2 environments.

II To compare rust reaction $\times$ awn type means, compute LSD $(0.05)$ as $t(\mathrm{SD})\left(\left[n_{1}+n_{2}\right] / n_{1} n_{2}\right)^{1 / 2}$, where $n_{1}$ and $n_{2}$ are the number of observations (no. of genotypes per class $\times$ no. of replicates $\times$ no. of environments) used to compute each mean.

between resistant and susceptible NILs from the $L r 41$ source (for grain yield, $1030 \mathrm{~kg} \mathrm{ha}^{-1}$ ) than the $\mathrm{Lr} 42$ source $\left(550 \mathrm{~kg} \mathrm{ha}^{-1}\right)$. This yield compression from $\mathrm{Lr} 42$ corresponded with visual observations of leaf rust severity and stay-green ratings. Differences in green-leaf retention of $R$ and $S$ NILs from $L r 42$ were not as obvious as those from $L r 41$, which translated into significant $(P<0.01)$ gene source $\times$ leaf rust reaction interactions for stay-green readings (Table 1 ). Comparison of resistant Lr41 NILs with resistant Lr42 NILs (Table 3) revealed only a slight advantage $(P=0.05)$ of $L r 41$ for yield $\left(150 \mathrm{~kg} \mathrm{ha}^{-1}\right)$ and 1000-kernel weight $(1.1 \mathrm{~g})$.

\section{Quality Attributes}

The SKCS results in Table 4 showed a small but positive effect on kernel diameter for each source of resistance $(R$ vs. $S)$ and for awnedness $\left(\mathrm{A}^{+}\right.$vs. $\left.\mathrm{A}^{-}\right)$. The 0.1- to 0.2-mm difference would not have significant market value at the kernel diameter levels observed in this genetic background. Values of 2.2 to $2.5 \mathrm{~mm}$ are more likely to be targeted in HRW wheat breeding programs. Nevertheless, these results demonstrate a slight advantage of leaf rust resistance and awns for kernel size that is consistent with trends in kernel weight (Table 2). The presence of awns did not compensate for the loss of resistance (compare $\mathrm{RA}^{+}$vs. $\mathrm{SA}^{+}$, Table 4).

Though differences among the genotypic classes were detectable for kernel hardness, they were either inconsistent between the resistance gene sources or were not sufficient to affect end-use quality of HRW wheat (Table 4). Leaf rust resistance did provide a significant advantage in flour yield, equaling 1.4 to 2.0 percentage units, whereas awns did not. With $L r 41$, that advantage was greater with awns than without, as indicated by significant interactions for series $41 \mathrm{~A}$. The $\mathrm{SA}^{-}$class had relatively low flour yield as well as small kernel diameter and kernel weight. Altogether these results imply a milling quality advantage associated with leaf rust resistance that was unmatched by the presence of awns. Under heavy leaf rust infection in Kansas, the Lr41 gene also increased milling quality in HRW wheat by increasing flour yield and shifting the kernel size distribution toward larger kernels (Cox et al., 1997).

The genotypic classes performed similarly for wheat protein quantity and for protein quality as measured by the mixograph. One exception was the mixogram curve width at 2 min past peak dough development for resistant and susceptible lines (Table 4). The greater width of susceptible types implies greater mixing tolerance, which might be associated with greater flour protein content caused by stress-induced senescence of the flag leaf, much as drought stress elevates flour protein content in hard red spring wheat (Guttieri et al., 2000). However, the resistant isolines tended to have higher flour protein content, particularly in the 41A series where the $R$ and $S$ means were 116 and $112 \mathrm{k} \mathrm{kg}^{-1}(P<$ 0.01 , data not shown).

Without experiments conducted in the absence of disease, we cannot rule out the alternative explanation that these resistance genes may affect mixing tolerance or gluten strength through linkage with other genes introgressed from $T$. tauschii. Those experiments were performed by Cox et al. (1997), who showed that bakemixing time and water absorption were lower in the presence of $L r 41$. Mixing tolerance based on curve width was unaffected, and baking performance did not appear to be negatively affected in limited observations. The level of mixing tolerance reduction we observed did not significantly change the overall appearance or visual rating of the mixogram between classes (Table 4). In addition, mixing time varied among classes within the acceptable range of 4.5 to $6.4 \mathrm{~min}$ but was not influenced by either rust reaction or awn type (data not shown). Therefore, the effect of leaf rust reaction or awn type 
Table 5. Single-kernel characterization and wheat protein means for testing main effects and interactions of leaf rust resistance gene background and leaf rust reaction across three Oklahoma environments.

\begin{tabular}{|c|c|c|c|c|}
\hline \multicolumn{2}{|c|}{ Genotypic class description $\dagger$} & \multicolumn{2}{|c|}{ Single-kernel characterization } & \multirow[b]{2}{*}{$\begin{array}{l}\text { Wheat } \\
\text { protein }\end{array}$} \\
\hline $\begin{array}{l}\text { Resistance } \\
\text { gene source }\end{array}$ & $\begin{array}{l}\text { Leaf rust } \\
\text { reaction } \%\end{array}$ & $\begin{array}{c}\text { Kernel } \\
\text { diameter }\end{array}$ & $\begin{array}{c}\text { Kernel } \\
\text { hardness }\end{array}$ & \\
\hline & & mm & & $\mathrm{g} \mathrm{kg}^{-1}$ \\
\hline Lr41 & $\mathbf{R}+\mathbf{S}$ & 2.0 & 75 & 123 \\
\hline$L r 42$ & $\mathbf{R}+\mathbf{S}$ & 2.0 & 75 & 123 \\
\hline$F$-test for $L r 41$ vs. $L r 42$ & & NS & NS & NS \\
\hline$L r 41+L r 42$ & $\mathbf{R}$ & 2.1 & 74 & 124 \\
\hline$L r 41+L r 42$ & $\mathbf{S}$ & 1.9 & 76 & 121 \\
\hline$F$-test for R vs. $\mathbf{S}$ & & $* *$ & $* *$ & $* *$ \\
\hline Lr41 & $\mathbf{R}$ & 2.1 & 74 & 125 \\
\hline & $\mathbf{S}$ & 1.9 & 76 & 120 \\
\hline$L r 42$ & $\mathbf{R}$ & 2.0 & 75 & 123 \\
\hline & $\mathbf{S}$ & 1.9 & 76 & 122 \\
\hline$F$-test for interactions & & $*$ & NS & $* *$ \\
\hline$t(\mathrm{SD}) \dagger$ & & 0.3 & 8 & 10 \\
\hline
\end{tabular}

* Significant at $\boldsymbol{P}=\mathbf{0 . 0 5}$.

$* *$ Significant at $\boldsymbol{P}=\mathbf{0 . 0 1}$.

$\dagger \boldsymbol{R}=$ resistant; $\mathbf{S}=$ susceptible to leaf rust.

$\$$ To compare source $\times$ rust reaction means, compute LSD $(0.05)$ as $t(\mathrm{SD})\left(\left[n_{1}+n_{2}\right] / n_{1} n_{2}\right)^{1 / 2}$, where $n_{1}$ and $n_{2}$ are the number of observations (no. of genotypes per class $\times 3$ environments $\times 3$ replicates) used to compute each mean.

on dough-handling properties was either minor or nonexistent.

Only those quality attributes showing significant genotypic effects were reported for series 41/42 (Table 5). Resistance increased wheat protein content, more so for $L r 41$ than for $L r 42$ (interaction significant at $P=$ $0.01)$. The parallel comparison in series $41 \mathrm{~A}\left(\mathrm{RA}^{+}\right.$vs. $\mathrm{SA}^{+}$, Table 4) did not produce the same result, so we cannot conclude in general terms that leaf rust resistance leads to a substantially favorable change in protein content. Consistency was found, however, for kernel diameter patterns. Kernel diameter increased by $0.2 \mathrm{~mm}$ with resistance, averaged for $L r 41$ and $L r 42$. Small differences were also found in kernel hardness but not of the expected magnitude to affect milling quality.

\section{CONCLUSIONS}

Awnletted cultivars will not likely win acceptance over the traditional awned types in the southern Great Plains unless they possess, or are provided, protection from leaf rust. Either resistance gene would provide a suitable source, though $L r 41$ offered a slight advantage, at most, for grain yield and thousand-kernel weight. Based on our results, awnletted types with a highly susceptible reaction are expected to suffer significant yield losses compared with resistant awned types and possibly with susceptible awned types. In the Century background, the combined effect of both genes on yield loss equaled about $30 \%$, as a mean across both resistance gene sources. Genes controlling the two traits generally acted additively but with unequal effects. Awns improved physical characteristics of grain quality (test weight, kernel weight, and kernel size), but awns did not provide a grain yield advantage that either was comparable to the yield advantage of leaf rust resistance or was consistent between series of NILs. Resistant awnlet- ted cultivars constitute a worthy breeding alternative to the more traditional awned types, but protection from leaf rust alone does not appear sufficient to restore the expected loss in test weight of awnletted types.

\section{REFERENCES}

AACC. 1995. Approved methods of the American Association of Cereal Chemists. Methods 39-70, 12-10A, and 54-40. AACC, St. Paul, MN.

Bockus, W.W., J.A. Appel, R.L. Bowden, A.K. Fritz, B.S. Gill, T.J. Martin, R.G. Sears, D.L. Seifers, G.L. Brown-Guedira, and M.G. Eversmeyer. 2001. Success stories: Breeding for wheat disease resistance in Kansas. Plant Dis. 85:435-461.

Browder, L.E. 1971. Pathogenic specialization in cereal rust fungi, especially Puccinia recondita f. sp. tritici: Concepts, methods of study, and application. USDA Tech. Bull. 1422. U.S. Gov. Print. Office, Washington, DC.

Carver, B.F. 1994. Genetic implications of kernel NIR hardness on milling and flour quality in bread wheat. J. Sci. Food Agric. 65:125-132.

Carver, B.F., W.E. Whitmore, and E.L. Smith. 1993. Registration of three pairs of awned vs. awnletted near-isolines of hard red winter wheat. Crop Sci. 33:885.

Cox, T.S., R.K. Bequette, R.L. Bowden, and R.G. Sears. 1997. Grain yield and breadmaking quality of wheat lines with the leaf rust resistance gene Lr41. Crop Sci. 37:154-161.

Cox, T.S., W.J. Raupp, and B.S. Gill. 1994. Leaf rust-resistance genes Lr41, Lr42, and Lr43 transferred from Triticum tauschii to common wheat. Crop Sci. 34:339-343.

Drijepondt, S.C., Z.A. Pretorius, D. van Lill, and F.H.J. Rijkenberg. 1990. Effect of Lr34 resistance on leaf rust development, grain yield, and baking quality in wheat. Plant Breed. 105:62-68.

Gooding, M.J., J.P.R.E. Dimmock, J. France, and S.A. Jones. 2000. Green leaf area decline of wheat flag leaves: the influence of fungicides and relationships with mean grain wheat and grain yield. Ann. Appl. Biol. 136:77-84.

Guttieri, M.J., R. Ahmad, J.C. Stark, and E. Souza. 2000. End-use quality of six hard red spring wheat cultivars at different irrigation levels. Crop Sci. 40:631-635.

Krenzer, G., R. Austin, and C. Luper. 1998. Wheat grain yield from variety trials 1997-98. PT 98-22, Vol. 10, No. 22. Oklahoma Coop. Ext. Serv.

Krenzer, G., R. Kochenower, R. Austin, and C. Luper. 1999. Wheat grain yield from wheat variety trials 1998-99. PT 99-18, Vol. 11, No. 18. Oklahoma Coop. Ext. Serv.

McKenzie, H. 1972. Adverse influence of awns on yield of wheat. Can. J. Plant Sci. 52:81-87.

Olugbemi, L.B., R.B. Austin, and J. Bingham. 1976. Effects of awns on the photosynthesis and yield of wheat, Triticum aestivum. Ann. Appl. Biol. 84:241-250.

Peterson, R.F., A.B. Campbell, and A.E. Hannah. 1948. A diagrammatic scale for estimating rust intensity on leaves and stems of cereals. Can. J. Res. Sect. C 26:496-500.

Singh, R.P., and J. Huerta-Espino. 1997. Effect of leaf rust resistance gene Lr34 on grain yield and agronomic traits of spring wheat. Crop Sci. 37:390-395.

Smith, E.L., R.C. Sharma, O.G. Merkle, E.E. Sebesta, R.L. Burton, J.A. Webster, R.M. Hunger, D.C. Abbott, B.F. Carver, and G.H. Morgan. 1989. Registration of Century wheat. Crop Sci. 29:1093-1094.

Stakman, E.C., D.M. Stewart, and W.Q. Loegering. 1962. Identification of physiologic races of Puccinia graminis var. tritici. USDA Publ. E617. U.S. Gov. Print. Office, Washington, DC.

Weyhrich, R.A., B.F. Carver, and B.C. Martin. 1995. Photosynthesis and water-use efficiency of awned and awnletted near-isogenic lines of hard red winter wheat. Crop Sci. 35:172-176.

Weyhrich, R.A., B.F. Carver, and E.L. Smith. 1994. Effects of awn suppression of grain yield and agronomic traits in hard red winter wheat. Crop Sci. 34:965-969. 